\title{
"Pairing assistance": the effective way to solve the breakdown of health services system caused by COVID-19 pandemic
}

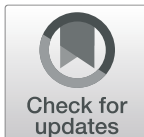

Tianxiang Chen ${ }^{1,2}$, Ying Wang ${ }^{1}$ and Lei Hua ${ }^{1,2^{*}}$ (D

\begin{abstract}
The most terrifying thing about pandemic could be the large number of patients running against the health service system, which causes a serious shortage of health resources, especially medical personnel. Plotting mortality and diagnosis rates against medical staff resources in 16 cities in Hubei Province, where the epidemic was initially concerned and the most severe, shows a significant negative correlation, indicating the critical role of medical staff resources in controlling epidemics. Nevertheless, it is difficult to ensure that there exist enough medical personnel in cities severely hit by the outbreak. China provides solutions by adopting nationwide "pairing assistance" measures with at least one province assisting one city to alleviate pressure in the most severe area. By plotting the number of patients receiving treatment against day, it is clear that implementing "pairing assistance" is a turning point in China's fight against epidemics.
\end{abstract}

Keywords: Pairing assistance, Health resources, Health service system, Medical personnel, COVID-19 pandemic

\footnotetext{
* Correspondence: leihuapir@gmail.com; leihuapir@outlook.com

${ }^{1}$ School of Government, Sun Yat-sen University, Guangzhou, Guangdong,

China

2Department of Public Administration, Nanfang College of Sun Yat-sen

University, Guangzhou, Guangdong, China
}

(c) The Author(s). 2020 Open Access This article is licensed under a Creative Commons Attribution 4.0 International License, which permits use, sharing, adaptation, distribution and reproduction in any medium or format, as long as you give appropriate credit to the original author(s) and the source, provide a link to the Creative Commons licence, and indicate if changes were made. The images or other third party material in this article are included in the article's Creative Commons licence, unless indicated otherwise in a credit line to the material. If material is not included in the article's Creative Commons licence and your intended use is not permitted by statutory regulation or exceeds the permitted use, you will need to obtain permission directly from the copyright holder. To view a copy of this licence, visit http://creativecommons.org/licenses/by/4.0/. The Creative Commons Public Domain Dedication waiver (http://creativecommons.org/publicdomain/zero/1.0/) applies to the data made available in this article, unless otherwise stated in a credit line to the data. 
An epidemic of Coronavirus disease 2019 (COVID-19), which was first identified in Wuhan City, Hubei Province, China in late December 2019, has spread throughout the world rapidly. The coronavirus crisis in China has abated after 2 months of hard work, while the rest of the world has sunk into an increasingly complex quagmire. Scholars own China's success in controlling COVID-19 to aggressive control measures, such as shutting down industrial and commercial restrictions, monitoring infected person and preventing cross-infection [1-5]. However, the terrifying thing about a pandemic is that the influx of patients overloads the health services system, which leads to a serious shortage of health resources, especially for medical personnel.

By plotting mortality (by Mar 31, 2020) and diagnosis rates (the number of confirmed cases per 1000 population by Mar 31, 2020) against medical personnel resources (the number of medical personnel per 1000 population before the COVID-19 pandemic) in 16 cities in Hubei Province where the virus epicenter in China, we find a significant negative correlation shown in Fig. 1, suggesting the crucial role of medical personnel resources in controlling the pandemic.

Thus, the medical personnel resources are so important that we should spare no effort to ensure adequate numbers of medical personnel. However, it is difficult for cities severely hit by the outbreak. China offers a solution by taking the nationwide "pairing assistance" measure, mobilizing 29 provinces to alleviate pressure on cities in Hubei province. For example, Wuhan, the provincial capital and the city hardest hit by the disease, had already received 32,572 medical personnel nationwide by Feb 20, 2020. Meanwhile, the other 16 cities with fewer technologies, personnel, and equipment than Wuhan were each partnered with at least one province that has sufficient capacity to assist them (Fig. 2).

The massive mobilization of medical staff, which aims to assist 16 cities besides Wuhan, was started on Feb 11, 2020, while the "pairing assistance" medical personnel got to work in pairing cities from Feb 13, 2020 (the 22nd day after the lockdown of Wuhan). Plotting the number of patients still undergoing treatment against the day clearly showed that the 22nd day after the lockdown of Wuhan was the turning point in fighting the epidemic (Fig. 3) although the total number of confirmed cases was still increasing rapidly at that time, illustrating the evident effect of "pairing assistance" on increasing the cure rate and relieving the pressure on health services system. It is worth noting that Shennongjia Forestry District has a high level of medical personnel resources (2.999 medical personnel per thousand population) and the smallest number of patients (only 11 confirmed cases), so it shows a different curve pattern.

In the context of globalization, what we can learn from China's "pairing assistance" is that the COVID19 pandemic is not just the business of a single province or a single country. Every sector, every individual and every country must be involved in the fight and support each other. Areas with less severe outbreaks should provide medical resources within their capabilities to the areas with the most severe pandemics. Only by taking the "pairing assistance" measures can we defeat COVID-19, because no one can be immune from the worldwide pandemic.
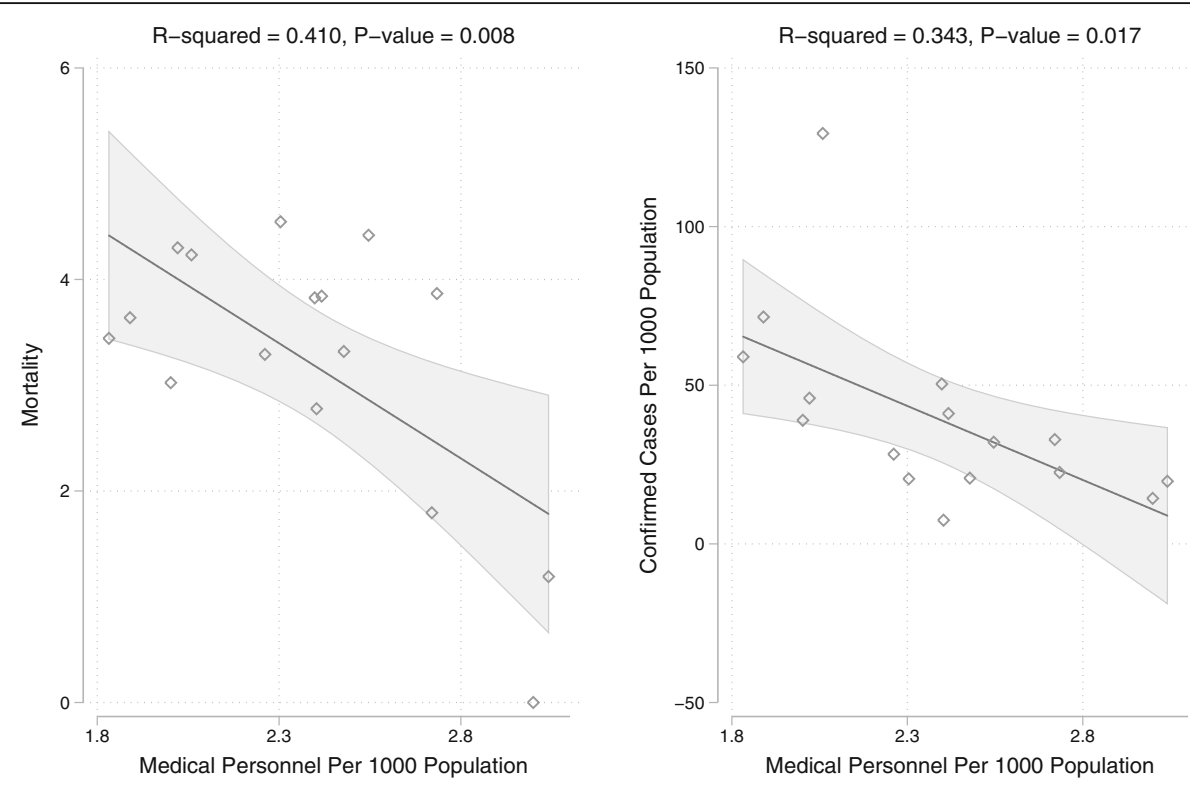

Fig. 1 Mortality and diagnosis rates against medical personnel resources 


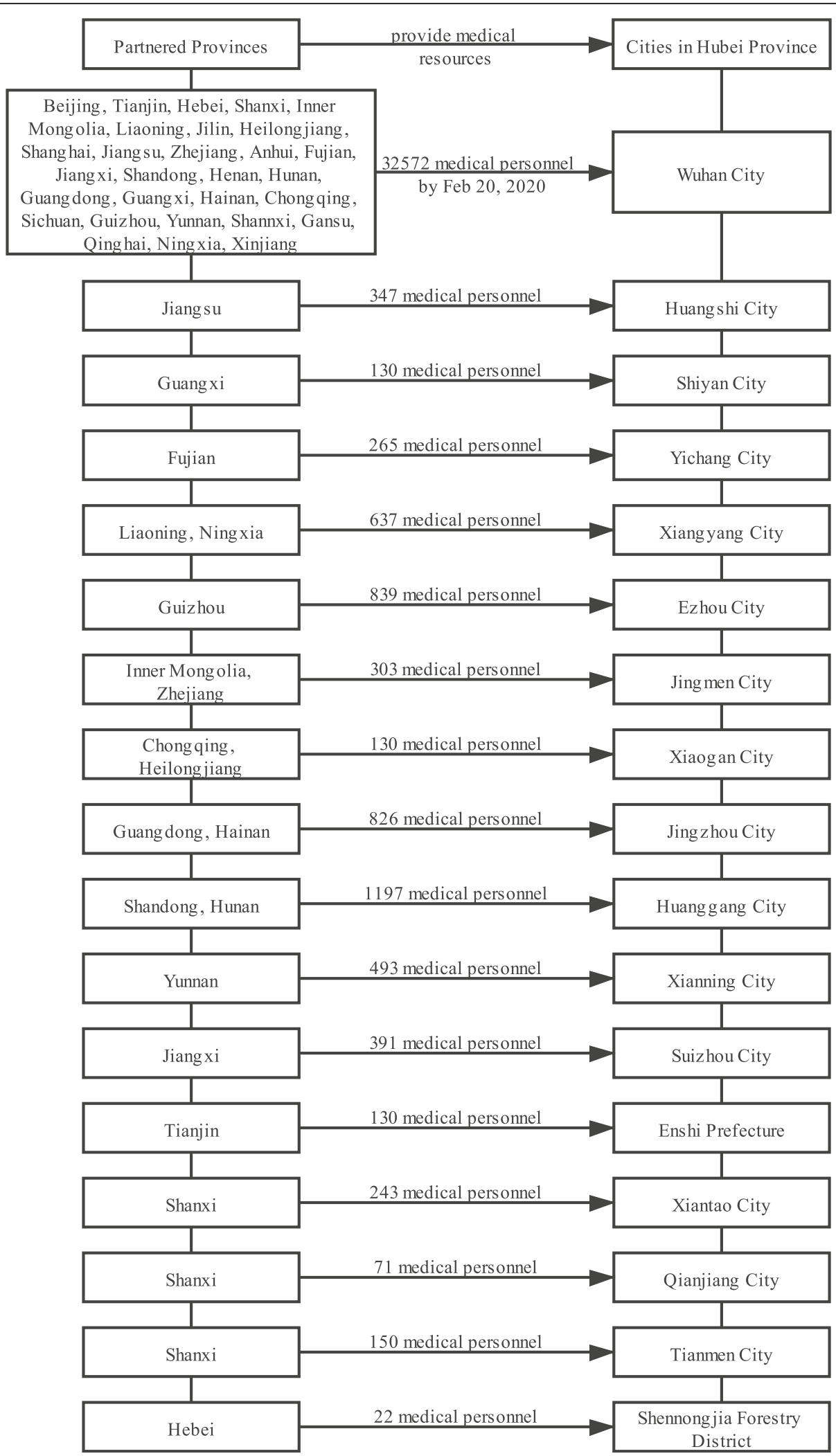

Fig. 2 Pairing assistance with 29 provinces mobilized to support cities in Hubei province 


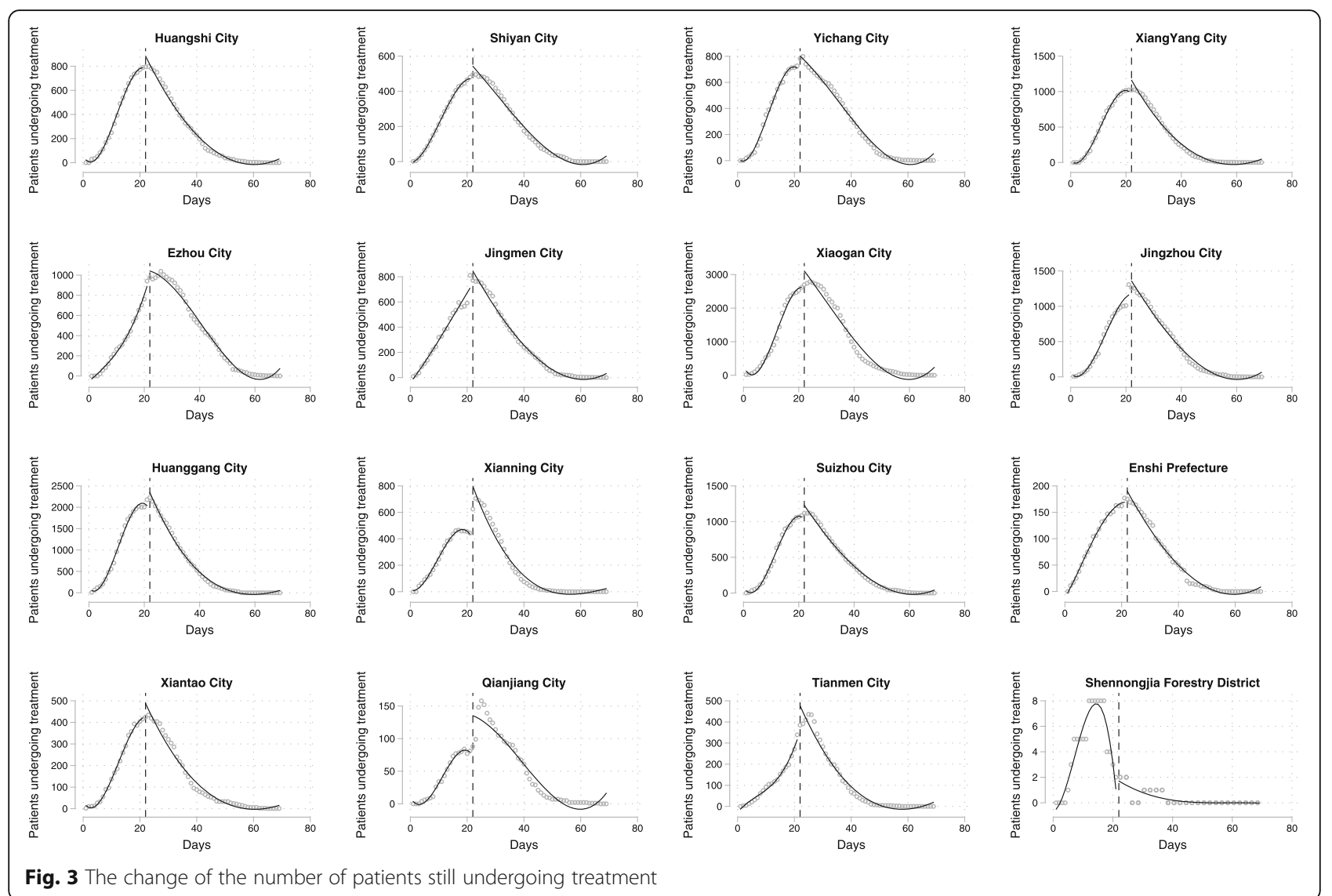

Fig. 3 The change of the number of patients still undergoing treatment

\section{Acknowledgments}

Not applicable.

\section{Authors' contributions}

TC and LH conceived of the study, collected statistical data, conducted analyses, and prepared the manuscript draft; YW collected statistical data and commented on manuscript drafts. All authors contributed to manuscript revision, read and approved the submitted version.

\section{Funding}

There was no funding for the research reported in the present article.

\section{Availability of data and materials}

The datasets are available from the corresponding author on reasonable request.

\section{Ethics approval and consent to participate}

Not applicable.

\section{Consent for publication}

Not applicable.

\section{Competing interests}

The authors declare that they have no competing interests.

Received: 9 April 2020 Accepted: 11 May 2020

Published online: 15 May 2020

\section{References}

1. Kupferschmidt K, Cohen J. Can China's COVID-19 strategy work elsewhere? Science. 2020;367:1061-2.
2. Deng $\mathrm{S}-\mathrm{Q}$, Peng $\mathrm{H}-\mathrm{J}$. Characteristics of and public health responses to the coronavirus disease 2019 outbreak in China. JCM. 2020;9:575.

3. Spector-Bagdady K. Hospitals should act now to notify patients about research use of their data and biospecimens. Nat Med. 2020;26:306-8.

4. Ian K. Lewis, Mirror Zhou, Elfie J.Y. Wang. The China Experience Understanding the Evolution of the COVID-19 Crisis (Updated on 6 April, 2020). 2020. https://www.mayerbrown.com/en/perspectives-events/ publications/2020/04/the-china-experience-understanding-the-evolution-ofthe-covid-19-crisis-updated-on-6-april-2020. Accessed 9 Apr 2020.

5. Kraemer MUG, Yang C-H, Gutierrez B, Wu C-H, Klein B, Pigott DM, et al. The effect of human mobility and control measures on the COVID-19 epidemic in China. Science. 2020. https://doi.org/10.1126/science.abb4218.

\section{Publisher's Note}

Springer Nature remains neutral with regard to jurisdictional claims in published maps and institutional affiliations.

\section{Ready to submit your research? Choose BMC and benefit from:}

- fast, convenient online submission

- thorough peer review by experienced researchers in your field

- rapid publication on acceptance

- support for research data, including large and complex data types

- gold Open Access which fosters wider collaboration and increased citations

- maximum visibility for your research: over $100 \mathrm{M}$ website views per year

At BMC, research is always in progress.

Learn more biomedcentral.com/submissions 